\title{
RESOURCE APPRAISAL SIMULATION FOR PETROLEUM IN THE ARCTIC NATIONAL WILDLIFE REFUCE, ALASKA
}

Compiled by J.J. Hansen and R.W. Kornbrath

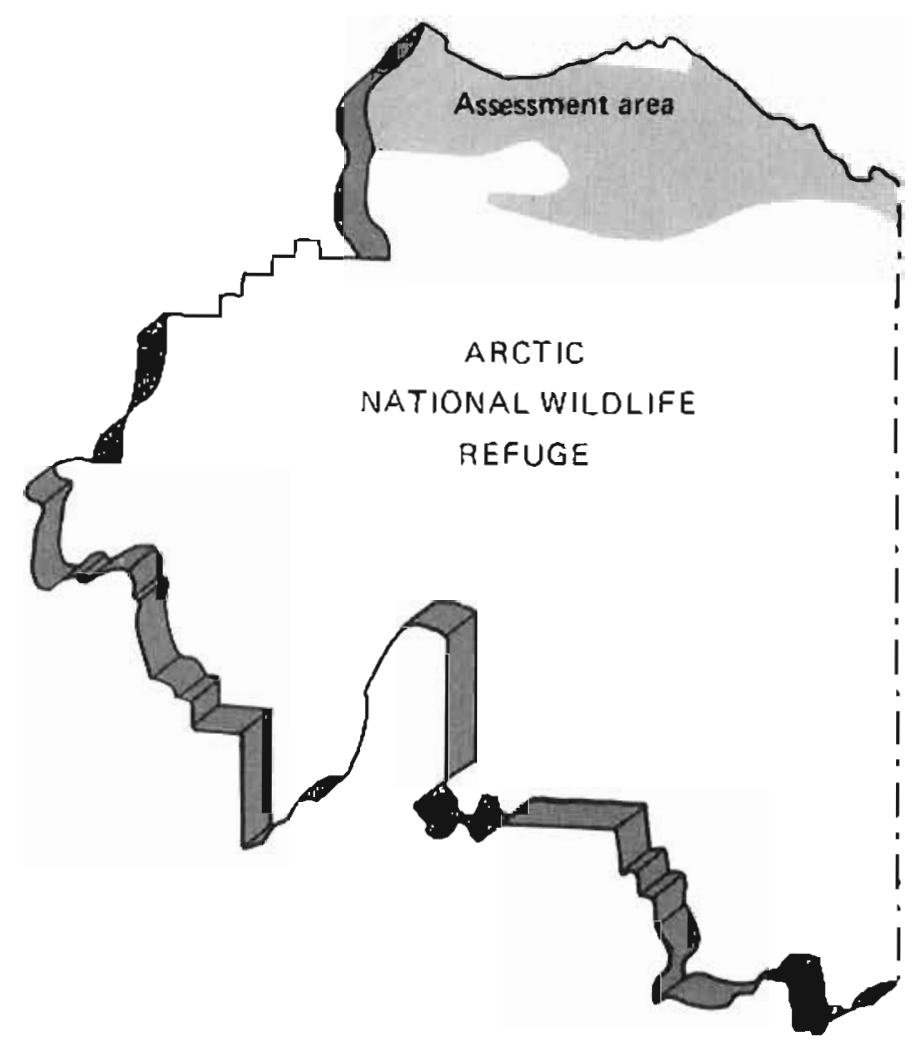

PROFESSIONAL REPORT 90

Publishcd by

State of Alaska

Department of Natural Resources

Division of Geological \& Geophysical Surveys

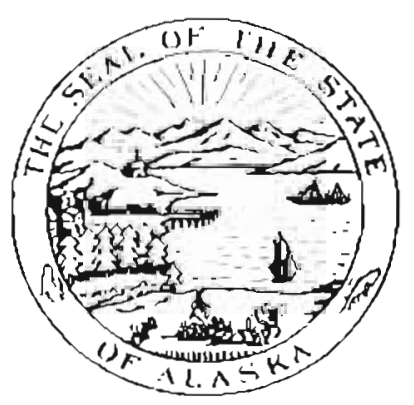




\section{RESOURCE APPRAISAL SIMULATION FOR PETROLEUM IN THE ARCTIC NATIONAL WILDLIFE REFUGE, ALASKA}

Compiled by J.\}. Hansen and R.W. Kornbrath

Division of Geological \& Ceophysical Surveys

Professional Report 90 


\section{STATE OF ALASKA}

Bill Sheffield, Governor

Esther C. Wunnicke, Commissioner, Department of Natural Resources

Ross G. Schaff, Director and State Geologist

This Yeport was prepared at the request of the U.S. Department of the interior by the State of Alaska Department of Natural Resources according to the Memorandum of Understanding signed by both agencies in 1985. DQGS publications are available at: Alaska National Bank of the North Bidg. (2nd floor), Geisc Rd. and University Ave., Fairbanks; $3601 \mathrm{C}$ St. (10th floor), Anchorage; 400 Willoughby Center (4th floor), Juneau; and the State Office Bldg., Ketchikan. Mail orders should be addressed to DGGS, 794 University Ave. (Basement), Falrbanks, AK 99709. Cost $\$ 2$. 


\section{FOREWORD}

In 1985, the Secretary of the U.S. Department of the Interior and the Commissioner of the Alaska Department of Natural Resources signed an agreement to share geologic and geophysical data collected from the Arctic National Wildlife Refuge (ANWR). Scientists of the Department of Natural Resources analyzed these data and prepared estimates of the oil-and-gas potential of the coastal plain of ANWR, as stipulated in the agreement. These estimates are reported in this document.

Ross G. Schaff

Director and State Geologist 


\section{CONTENTS}

Introduction ........................... 1

Assessment results . . . . . . . . . . . . . . . . . . . . . . . 1

Geologic plays .......................... 3

Procedures for oil-and-gas resource appraisals . . . . . . . . . . . . 3

Appendix - Areal distribution, input parameters, and resources in

place for geologic plays . . . . . . . . . . . . . . . 5

\section{FIGURES}

Figure 1. Areal distribution, input parameters, and resources in place for the Kekiktuk Play, Arctic National Wildlife Refuge, Alaska ......................

2. Areal distribution, input parameters, and resources in place for the Lisburne North Play, Arclic National

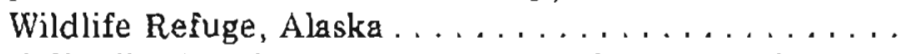

3. Areal distribution, input parameters, and resources in place for the Lisburne South Play, Arctic National Wildlife Refuge, Alaska . . . . . . . . . . . . . . . . .

4. Areal distribution, input parameters, and resources in place for the Permian-Triassic Clastics North Play, Arctic National Wildlife Refuge, Alaska ...........

5. Areal distribution, input parameters, and resources in place for the Permian-Triassic Clastics South Play, Arctic National Wildlife Refuge, Alaska . . . . . . . . . .

6. Areal distribution, input parameters, and resources in place for the Kemik-Thomson Play, Arctic National Wildlife Refuge, Alaska..................

7. Areal distribution, input parameters, and resources in place for the Post-Albian Clastics Play, Arctic National Wildlife Refuge, Alaska. . . . . . . . . . . .

8. Stratigraphic column and oil-and-gas summary for plays in the Arctic National Wildlife Refuge, Alaska .......

TABLES

Table 1. Total oil, ANWR petroleum-resource assessment. . . . . . 2

2. Total gas, ANWR petroleum-resource assessment ....... 2

3. Total deposit size, ANWR petroleum-resource assessment. . 2

4. Total resources, ANWR petroleum-resource assessment. . . 2 
PROFESSIONAL REPORT 90

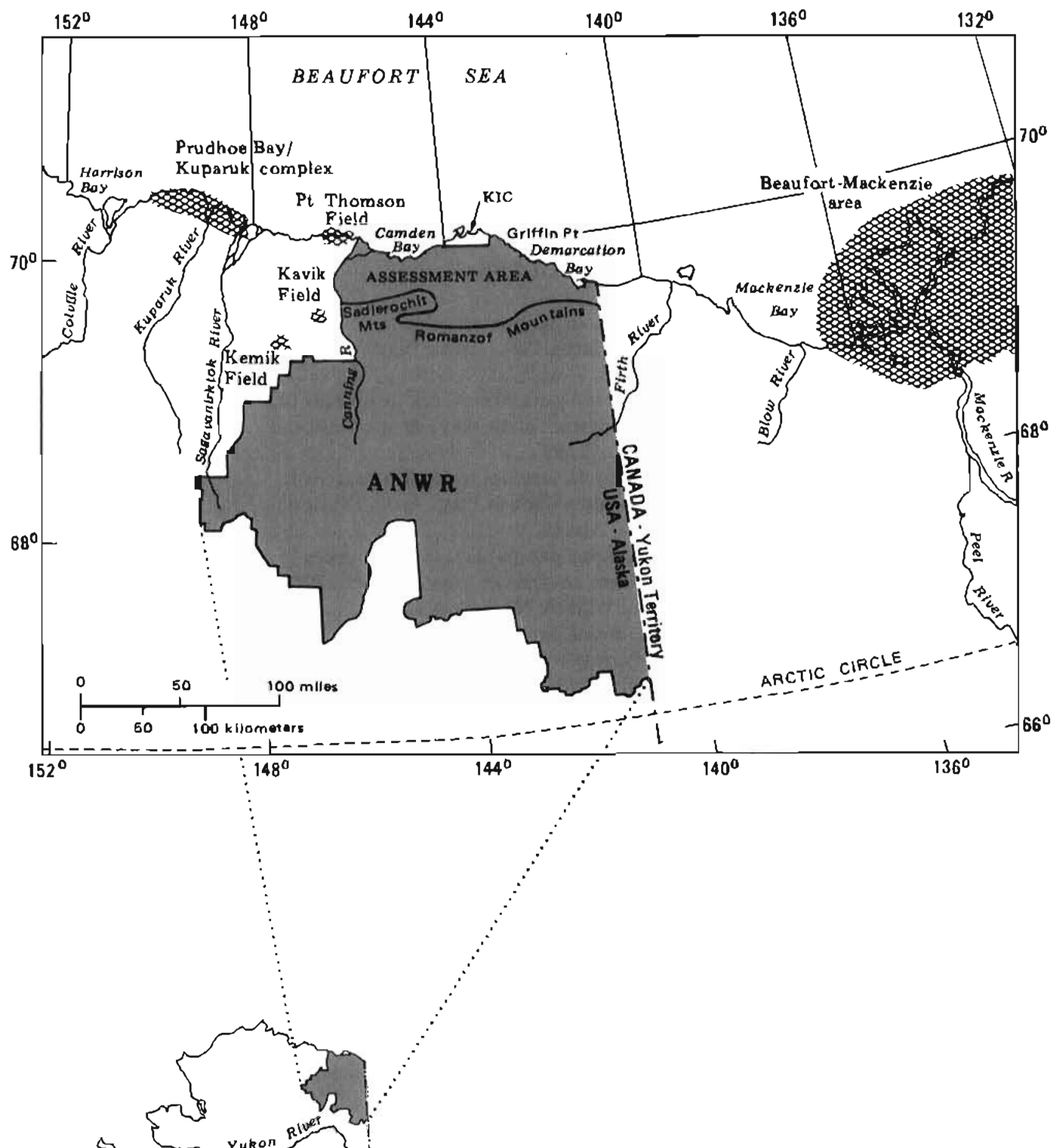

Location map of the assessment area in the Arclic National Wildlife Refuge. The North Slope of Alaska contains nime hnown significant oil-and-gos fields with proven and inferred original recoverable reserves of about 15.4 billion barrels of oil and 32.0 trillion cubic feel of gas. The Beaufort-Mackenzic area of Canada contains 39 oil-and-gas fields with proven and in/erred original recoverable reserves of aboul 8.5 billion barrels of oil and 65.0 Irillion cubic feet of gas. KIC denoles land owned by the Kaklovik Inupiat Corporalion. 


\title{
RESOURCE APPRAISAL SIMULATION FOR PETROLEUM IN THE ARCTIC NATIONAL WILDLIFE REFUGE, ALASKA
}

\author{
Compiled by J.J. Hansen ${ }^{1}$ and R.W. Kornbrath ${ }^{2}$
}

\section{INTRODUCTION}

This report presents the results of the State's preliminary appraisal of the potential for undiscovered petroleum resources on the coastal plain of the Arctic National Wildlife Refuge (ANWR), Alaska. The assessment area is located north of the Saderochit and Romanzof Mountains between, the Canning River and the Canadian border. The study area does not include that portion of the coastal plain from eastern Camden Bay to Griffin Point (owned by the Kaktovlk Inupiat Corporatlon ${ }^{2}$ ) or stale-submerged lands offshore from ANWR.

Members of the appraisal panel from the Alaska Department of Natural Resources include C. Ariey, J.E. Decker, 3.J. Hansen, R.W. Kornbrath, D.L. Krouskop, C.G. Mull, G.H. Pessel, M.S. Robinson, T.N. Smith, and S.M. Weum. B.H. White and R. Anderson (U.S. Bureau of Mines) and E.L. Phillips (Alaska Department of Natural Resources) assisted in the computer analysis of the data.

A resource appraisal of ANWR was completed in 1980 by the U.S. Geological Survey, At that time, the available data consisted of limited gravity and aro. magnetic surveys augmented by some geologic mapping. Since then, additjonal geologic studies, two proprietary gravity surveys, and two seismic surveys have been conducled. Interpretation of this new information has resulted in revised hypotheses about the geologic evolution of the coastal plain.

The methodology used to assess the resource potential of the coastal plain of ANWR is the Resource Appraisal Simulation for Petroleum (RASP), which was developed by the U.S. Department of Interior Office of Minerals Policy and Research Analysis. RASP is a simulation (or modeling) procedure that geoscientists use to assess the undiscovered oil-and-gas potential of frontier basins. The basic unit of anaiysis is the geologic

\footnotetext{
1 Alaska Division of Geological and Geophysical Surveys, P.O. Box 7028, Anchorage, Alaska 89610.

2 An additional assessmont that includes tho KIC lands was performed by the Alaska Department of Natural Resources.
}

play, which is defined as a stratigraphic unit in a relatively homogeneous geologic setting. A basin will normally consist of one or more plays of interest; the geologic plays for this appraisal are presented in figures 1 through 7 (app.).

Resource estimates are presented as probability distributions that reflect the uncertalnty inherent in appraising undiscovered resources. The resources estimated to exist in each play are combined to produce an estimate of the total 'undiscovered, conditional resources in place' as barrels of oil, cubic feet of gas, and barrels of oil equivalent for the study area. In addition, a probability distribution of the deposit size is generated Cor each play and for the total resources in place. Deposit size is importanl for economlc considerations; for instance, less than 350 million barrels of recoverahle oil in ANWR may not be commercially viable. A more detailed discussion of the RASP methodology is included on page 3 .

\section{ASSESSMENT RESULTS}

The results of the petroleum-resource assessment are summarized in tables 1 through 4. Probability distribu. tions for total oil, total gas, total barrels of oil equiva. lent, and oil-and-gas deposit sizes are presented at various fractiles that range from 0.99 to 0.01 . The distribution values may be interpreted as follows. The 0.95 fractile means that there is a 95 -percent chance that at least that amount of the associated resource is present. For oil, there is a 95-percent chance that ANWR contains at least 80 million barrels of oil. Similarly, there is a 1-percent chance that ANWR contains at least 45.78 billion barrels of oil. The 0.50 fractile is not the most likely case of occurrence. Rather, it is the median of the distribution and indicates a 50 -percent chance that the quantity of resource present could be greater or less than its associated value.

The results in tables 1 and 2 show that in the range between the 95 th and 5 th fractiles, the resource potential of ANWR ranges from 0.08 to 26.52 billion barrels of oil ( $\mathrm{BBO}$ ) and from 0.71 to 43.62 trillion 
Table 1. Tolal oil, ANWR petroleum-resource assessment.

Fractile

0.99
0.98

0.97

0.96

0.95

0.90

0.75

0.50

0.25

0.10

0.05

0.04

0.03

0.02

0.01

Minimum simulated oil

0.00

Average oil

7.22

Table 3. Tolol deposit size, ANWR pelroleum resource assessment.

$$
\begin{aligned}
& \text { Conditional, } \\
& 100 \% \text { oil }
\end{aligned}
$$

Fractile

$$
\text { (million barrels) }
$$

0.99

0.98

0.97

0.96

0.95

0.90

0.75

0.50

0.25

0.10

0.05

0.04

0.03

0.02

0.01

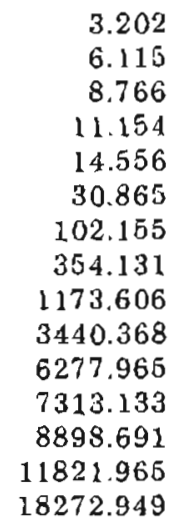

Minimum simulated deposit

Average

Maximum simulated deposit

Standard deviation
Standard deviation

9.66

Conditional, $100 \%$ gas

$$
\begin{array}{r}
0.00 \\
0.00 \\
0.01 \\
0.04 \\
0.08 \\
0.83 \\
1.28 \\
3.77 \\
9.18 \\
17.94 \\
26.52 \\
29.68 \\
34.14 \\
38.94 \\
45.78
\end{array}
$$

(billion $\mathrm{ft}^{3}$ )

$$
\begin{array}{r}
5.797 \\
10.252 \\
14.854 \\
19.868 \\
23.382 \\
45.115 \\
143.645 \\
509.171 \\
1721.490 \\
4846.398 \\
8912.465 \\
10861.937 \\
13492.098 \\
18052.875 \\
26867.359 \\
\\
0.40 \\
2143.70 \\
125833.06 \\
\\
5768.84
\end{array}
$$$$
76941.38
$$

3762.19
Table 2. Total gas, ANWR pelroleum-resource assessment.

Fractile

Trillion $\mathrm{ft}^{8}$

0.99

0.98

0.08

0.97

0.96

0.95

0.90

0.75

0.50

0.25

0.10

0.05

0.04

0.03

0.02

0.01

0.26

0.40

0.56

0.71

1.42

3.74

8.64

17.77

31.94

43.62

46.66

52.67

62.26

76.24

Minimum simulated gas 0.00

Maximum simulated gas 159.92

Average gas 13.69

Standard deviation 15.76

Table 4. Tolal resources, ANWR petroleumresource assessmenl. (barrels of oil equivalent, $B O E$ )
Fractile

0.99

0.98

0.97

0.96

0.95

0.90

0.75

0.50

0.25

0.10

0.05

0.04

0.03

0.02

0.01

Minimum simulated

BOE

0.00

Average $\mathrm{BOE}$

9.64
Billion BOE

0.05

0.17

0.25

0.35

0.47

0.96

2.54

6.05

12.42

22.50

31.54

35.56

40.15

44.75

53.01
Maximum simulated BOE 89.93

Standard deviation 11.06 
cubic feet of gas (TCFG) in place, with an average value of $7.22 \mathrm{BBO}$ and 13.69 TCFG. The median value (the 50th practile) is $3.77 \mathrm{BBO}$ and 8.64 TCFG (tables 1 and 2).

The resource distributions are strongly skewed toward the low-probability, high-resource values, as indicated by the difference between the average and median values (tables 1 and 2). This indicates that while only small quantities of resources are assured, there is a small chance that very large quantities of resources exist in ANWR.

Deposit-size estimates are equally important. For oil, the potential deposit sizes at the 1-percent con lidence level range up to $18.27 \mathrm{BBO}$ in place, with an average value of $1.46 \mathrm{BBO}$ and a median value of $0.35 \mathrm{BBO}$. For gas, the potential deposil sizes at the 1-percent confidence level range up to 26.87 TCFG in place, with an average value of 2.14 'TCFG and a median value of 0.51 TCFG (table 3 ).

In summary, the results of this evaluation indicate that the ANWR coastal plain may contain large petro. leum deposits. On the basis of current data, large quantities of resources and large individual deposit sizes may occur within the coastal plain of ANWR. There is a 1-percent chance that the requisite parameters of source rock, timing, migration, reservoir rock, and trapping mechanisms have combined to generate up to 45.78 BBO and 76.24 TCFG in place in ANWR (tables 1 and 2). Assuming a recavery factor of 35 percent for oil, up to 16 billion barrels of recoverable oil may be present. This compares favorably with the original recoverable oil reserves of about 10 billion barrels in the Prudisoe Bay field.

\section{GEOLOGIC PLAYS}

T'he geologic play is the basic unit of analysis for resource assessment using the RASP methodology. Reservoir-quality rocks, known production, and trapping mechanisms are the most important parameters used to define specific plays in this assessment. Parameters such as thermal maturity, source-rock distribution, and timing are also requisite for a successful play. Specific plays used to assess the resource potential of ANWR include Kekiktuk (fig. 1), Lisbume North and South (figs. 2 and 3). Permian-Triassic Clastics North and South (figs. 4 and 5), Kemik-Thomson (fig. 6), and Post-Albian Clastics (fig. 7). A stratigraphic column and oil-and.gas summary for these plays are shown in figure 8 (app.).

The sandstone, conglomerate, and carbonate lithol. ogies of these plays have produced large quantities of oil and gas on the North Slope and in the Mackenzie Delta area of Canada. The combination of gelleration and migration of hydrocarbons from source shales and tining of trap formation has produced large fields. On the basis of surface studies and geologic modeling, similar favorable conditions may be present in the subsurface of ANWR.
Geologic field studies conducted by DGGS indicate the existence of complex relationships between various rock groups that comprise the geologic plays in the subsurface of the ANWR coastal plain. Simple structural closures, thrust-fault repetitions of rock units, and complex folds could provide mechanisms to structurally trap hydrocarbons. Truncation of rock units and facies changes could aiso result in stratigraphic traps.

Plays of the Kekiktuk, Kemik-Thomson, and Post-Albian Clastles (figs. 1, 6, and 7) are broad in scope and are anticipated to be present throughout the study area. However, based on possible truncation of the rock units by a major unconformity, plays of the Lisburne North and Permian-Triassic Clastics North (figs. 2 and 4) are less likely to occur in the study area.

\section{PROCEDURES FOR OIL AND.GAS RESOURCE APPRAISALS}

The procedure for the Resource Appraisal Simulalion for Petroleum (RASP) incorporales a 'play' ap. proach to pelroleum-resource assessment. 'The methodology focuses on the concept of a geologic play as the basic unit of geologic analysis. The play is defined as a stratlgraphic unit in a relatively homogeneous geologic setting.

A play approach to resource assessment of large basins or regions was chosen for the following reasons:

- The approach provides a direct assessment of the geologic characleristics -and their uncertainty-for the area of interest.

- The level of geologic detail provided by the play approach is sufficient to support a meaningfu] analysis.

- The approach does not require explicit identification and substantial detall for individual prospects.

- The approach recognizes regional trends within a play that enable prospects to be geologically correlated.

In essence, the play approach divides the traditional dry-hole risk factor into two components. The first component is the risk that is common to all prospects in the play because they share a common potential for source material, migration, timing, and reservoir rock. The second component is the risk that an individual prospect may have a geologic naw specific to it and independent of other prospects in the play. Finally, the approach does nol require actual discoveries in a play for assessment purposes. Judgments may be based on existing data and can explicitly reflect the uncertainty in those data.

Geoscientists familiar with the geology are asked to make three sets of probability judgments for each play. 
The first set of judgments concems the individual probabilities that each of four regional geologic characteristics common to the play area is favorable for the existence of petroleum accumulations. These regional characteristics are the existence of a petroleum source, favorabie timing, potential migration paths, and reservoir rock. The product of these four probabilities is the marginal-play probability, that is, the joint probability that all regional geologic characteristics necessary for the accumulation of petroleum in the play area are simultaneously favorable. The existence of each geologic characteristic is necessary, but not sufficient to forecast the existence of oil or gas deposits in the play. If oil or gas have been found in a particular play, the marginal-play probability is 1.0 . If none have been discovered in a play, additional probability judgments are necessary to determine the existence of hydrocarbon deposits.

The number of potentially drillable prospects in the play area, reservoir lithology (sandstone or carbonate), and petroleum mix (proportion of deposits within the play that are anticipated to oe oil rather than nonassociated gas) are also needed to evaluate each play. The RASP program assumes that petroleum accumula. tions exist only as gas deposits below 15,000 feel.

The second set of judgments is a set of probabilities that concerns the presence of three geologic characteristics that are common to the individual prospects within each play:

- Trapping mechanism. This defines the method that restricts hydrocarbon migration, which can be related to structure or stratigraphy, or both. A trap must have an areal extent of at least 600 acres with vertical closure of at least 5 feet.

- Effective porosity. The interconnected vold space that may hold hydrocarbons musi be equal to or greater than 3 percent.

- Hydrocarbon accumulation. Oil and gas must exist in at least 1 percent of a trap. This expresses the favorable relationships of source rock to reservoir rock and timing of hydrocarbon generalion to trap formation.
The probability judgment is conditional on the existence of these three geologic characteristics. The product of the three attribute probabilities is the conditional-deposit probability, that is, the probability that a particular prospect is an actual accumulation of oil or gas, given that all play attributes are favorable. The farniliar dry-hole risk factor is equal to one minus the product of the marginal-play probability and the conditional-deposit probability.

The third set of probability judgments involves the geologic parameters of the reservoir that determine the size of the potentlal deposits. These reservoir characteristics are area of closure, reservoir thickness, effecthe porosity, trap hill, reservoir depth, reservoir lithology, and hydrocarbon mix. Jointly, these parameters determine the potential reservoir volume for a deposil.

These three basic sets of judgments-geologic characteristics common to the play area, geologic characteristics common to the individual prospects within each play, and geologic parameters that deter. mine the size of the potential deposits-are made for each identified play and comprise the basic geologic data necessary for a resource appraisal.

The probability distribution for each characteristic is randomly sampled to simulate one possible state of geologic nature. For example, the probability distributlon for the number of potentialiy drillable prospects is sampled to determine the number of prospects that will be simulated for the play. The marginal-play probability is then sampled to determine whether the play will be simulated as unproductive or potentially productive. For each simulated prospect in a productive play, the conditlonal-deposit probability is sampled to determine whether that prospect will be treated as dry or as a deposit. The petroleum-mix probsbility is sampled for each deposit to simulate whether it contains oil or gas, but not both. All prospects in an unproductive play are automatically simulated to be dry. Each reservoirparameter distribution is sampled for each deposit to simulate its volume and reservolr characteristics. This sampling procedure is repeated 3,000 times in a typical Monte Carlo method, and the results are combined to develop probability distributions for oil, gas, barrels of oil equivalent in place, and deposil size. 


\section{APPENDIX}

Areal distribution, input parameters, and resources in place for geologic plays 


\begin{tabular}{|c|c|c|c|}
\hline \multicolumn{4}{|c|}{$\begin{array}{l}\text { Gas fraction }=0.40 \\
\text { Conditional resources in place }\end{array}$} \\
\hline Frscrile & $\begin{array}{l}\text { OIl } \\
\text { (million barrels) }\end{array}$ & $\begin{array}{c}\text { Gas } \\
\left\{\text { billion } \mathrm{t}^{3}\right\}\end{array}$ & $\begin{array}{c}\text { BOE } \\
\text { (million) }\end{array}$ \\
\hline 0.99 & 0.00 & 0.00 & 0.00 \\
\hline 0.95 & 0.00 & 0.00 & 0.00 \\
\hline 0.90 & 0.00 & 0.00 & 0.00 \\
\hline 0.75 & 0.00 & 0.00 & 0.00 \\
\hline 0.50 & 0.00 & 0.00 & 0.00 \\
\hline 0.25 & 0.00 & 0.00 & 0.00 \\
\hline 0.10 & 6.56 & 131.66 & 57.61 \\
\hline 0.05 & 105.72 & 377.90 & 196.04 \\
\hline 0.01 & 634.34 & 1591.72 & 860.35 \\
\hline Fractile & $\begin{array}{l}\text { Depo: } \\
\text { Condi } \\
100 \% \\
\text { imillion }\end{array}$ & & $\begin{array}{c}\text { Deposit size } \\
\text { Conditional. } \\
100 \% \text { gas } \\
\text { (billion ft }{ }^{3} \text { ) }\end{array}$ \\
\hline 0.99 & & & 2.376 \\
\hline 0.95 & & & 10096 \\
\hline 0.90 & & & 20.976 \\
\hline 0.75 & & & 48.852 \\
\hline 0.50 & & & $152.2 / 3$ \\
\hline 0.25 & 222 & & 4.32 .578 \\
\hline 010 & 559 & & 1025.895 \\
\hline 0.05 & 891 & & 1686.935 \\
\hline 0.01 & 3558 & & 4129.762 \\
\hline
\end{tabular}

\begin{tabular}{|c|c|c|c|c|c|c|c|c|}
\hline \multicolumn{4}{|c|}{ Altribute } & \multicolumn{5}{|c|}{$\begin{array}{l}\text { Probability inat atribute is } \\
\text { favorable or present }\end{array}$} \\
\hline \multirow{5}{*}{ 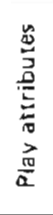 } & \multicolumn{3}{|l|}{ Hyarocarbon sourcos } & \multicolumn{5}{|c|}{1} \\
\hline & \multicolumn{3}{|l|}{ Timing } & \multicolumn{5}{|c|}{1} \\
\hline & \multicolumn{3}{|l|}{ Migration } & \multicolumn{5}{|c|}{1} \\
\hline & \multicolumn{3}{|l|}{ Potential resarvoir tacies } & \multicolumn{5}{|c|}{1} \\
\hline & \multicolumn{3}{|l|}{ Marginal-pla'v probability } & \multicolumn{5}{|c|}{1} \\
\hline \multirow{4}{*}{ 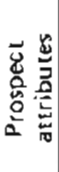 } & \multicolumn{3}{|l|}{ Trapping mechanism } & \multicolumn{5}{|c|}{0.25} \\
\hline & \multicolumn{3}{|l|}{ Effective porosity $(>3 \%)$} & \multicolumn{5}{|c|}{0.3} \\
\hline & \multicolumn{3}{|c|}{ Hydroc;arbon accumulahan } & \multicolumn{5}{|c|}{0.3} \\
\hline & \multicolumn{3}{|c|}{ Conditionst deposil probability } & \multicolumn{5}{|c|}{0.0225} \\
\hline \multirow{6}{*}{ 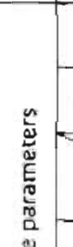 } & \multirow[b]{2}{*}{ Aeserwail lishology } & \multicolumn{2}{|c|}{ Sand } & \multicolumn{5}{|c|}{1} \\
\hline & & \multicolumn{2}{|c|}{ Carbonate } & \multicolumn{5}{|c|}{0} \\
\hline & \multirow{2}{*}{ Hydrocarbon mix } & \multicolumn{2}{|c|}{ Gas } & \multicolumn{5}{|c|}{0.4} \\
\hline & & \multicolumn{2}{|c|}{ Oil } & \multicolumn{5}{|c|}{0.6} \\
\hline & Fractiles & \multicolumn{7}{|c|}{ Probability of equal to of greater than } \\
\hline & Attribute & 1.00 & 0.95 & 0,75 & 0.50 & 0.25 & 0.06 & 0 \\
\hline$\stackrel{\stackrel{M}{E}}{\underline{Z}}$ & $\begin{array}{c}\text { Area of closure } \\
\left(\times 10^{3} \text { acres }\right)\end{array}$ & 0.6 & 1 & 3 & 5 & 15 & 25 & 100 \\
\hline$\frac{3}{8}$ & $\begin{array}{l}\text { Reservois thickoess? } \\
\text { vertical closure (it) }\end{array}$ & 5 & 25 & 60 & 75 & 100 & 200 & 1000 \\
\hline 芺 & Ellective porosity $\left(\%_{0}\right)$ & 3 & 4 & 6 & 8 & 12 & 16 & 20 \\
\hline$\vec{I}$ & Trap fill $\left\{x_{0}\right\}$ & 1 & 6 & 30 & 6O & 80 & 96 & 100 \\
\hline & $\begin{array}{l}\text { Reservoir depin } \\
\left\{\times 10^{3} \text { i1) }\right.\end{array}$ & 5 & 8 & 10 & 12 & 15 & 20 & 30 \\
\hline Num & $\begin{array}{l}\text { of of drillate prospects } \\
\text { piay characteristici? }\end{array}$ & 1 & 2 & 4 & 7 & 15 & 25 & 50 \\
\hline
\end{tabular}

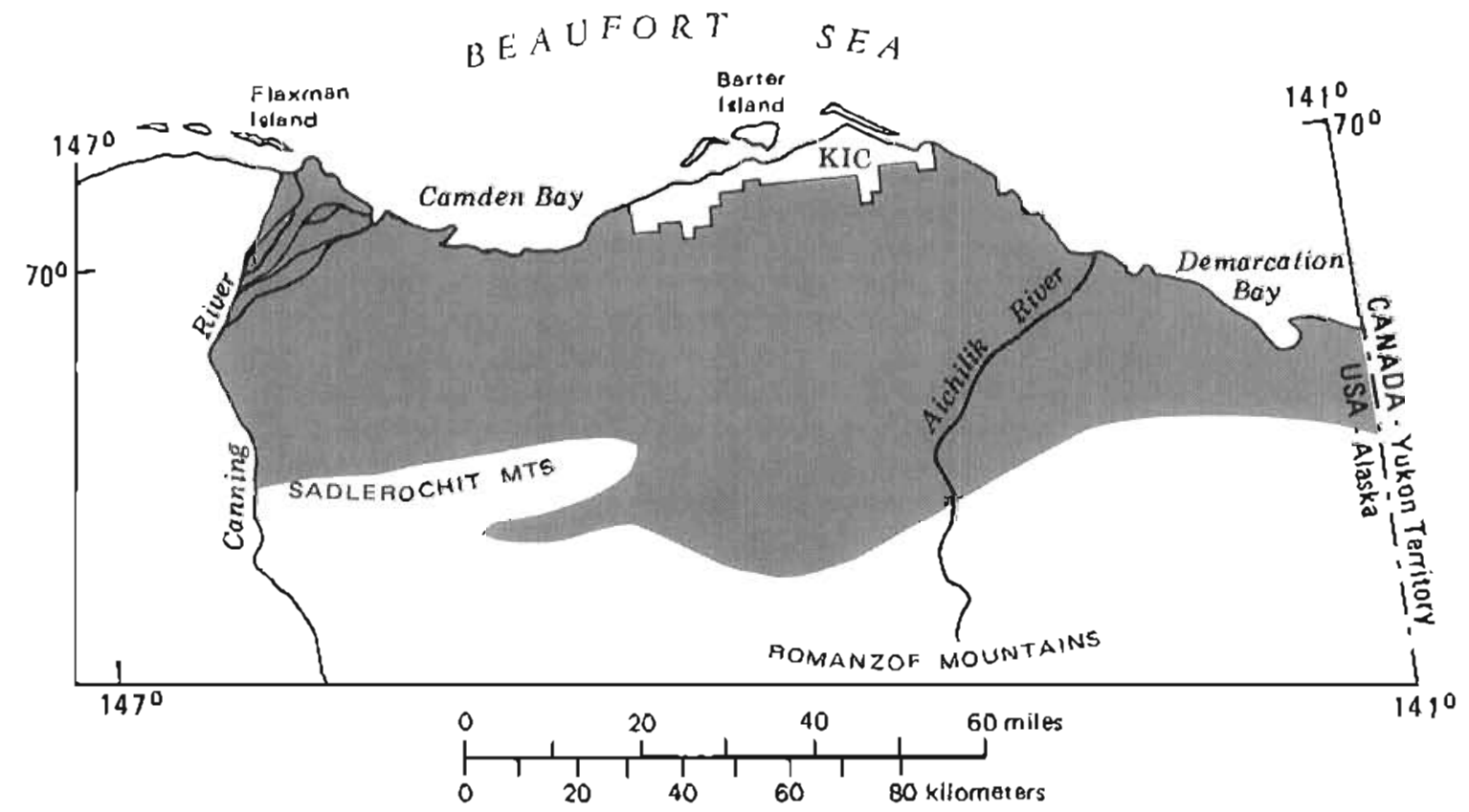

Figure 1. Areal distribution, inpul parameters, and resources in place lor the Kekiktuk Play, Arctic National Wildife Reluge, Alaska. 


\begin{tabular}{|c|c|c|c|}
\hline \multicolumn{4}{|c|}{$\begin{array}{l}\text { Gas traction }=0.40 \\
\text { Conditional resources in pirce }\end{array}$} \\
\hline Fracule & $\begin{array}{c}\text { Ois } \\
\text { (million barrels) }\end{array}$ & 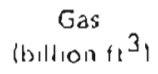 & $\begin{array}{c}\therefore O E E \\
\{\text { million }\}\end{array}$ \\
\hline 0.99 & 000 & 0.00 & 0.00 \\
\hline 0.95 & 0.00 & 0.011 & 0.00 \\
\hline 0.90 & 0.00 & 0.00 & 0.00 \\
\hline 075 & 000 & 000 & 0.00 \\
\hline 0.50 & 000 & 0.00 & 000 \\
\hline 0.25 & 0.00 & 0.00 & 0.00 \\
\hline U 10 & 000 & 000 & 0.40 \\
\hline 0.05 & 0.00 & 75.28 & 48.54 \\
\hline 0.01 & 234.23 & 670.64 & 325.42 \\
\hline Fractile & \multicolumn{2}{|c|}{$\begin{array}{l}\text { Conditional, } \\
\text { 100\% oil } \\
\text { \{millıon barress }\end{array}$} & $\begin{array}{c}\text { Deposit size } \\
\text { Conditionál, } \\
100 \% \text { gas } \\
\text { (ballion }\left(t^{3}\right)\end{array}$ \\
\hline 0.99 & \multicolumn{2}{|c|}{3.720} & 15.887 \\
\hline 0.95 & \multicolumn{2}{|c|}{9.020} & 25.298 \\
\hline 0.90 & \multicolumn{2}{|c|}{17.780} & 73.341 \\
\hline 075 & \multicolumn{2}{|c|}{42.483} & 146806 \\
\hline 050 & \multicolumn{2}{|c|}{35.310} & $29 ? 110$ \\
\hline 0.25 & \multicolumn{2}{|c|}{234.471} & 617,343 \\
\hline 0.10 & \multicolumn{2}{|c|}{461.101} & 1723.089 \\
\hline 0.05 & \multicolumn{2}{|c|}{536.209} & 1832462 \\
\hline 0.01 & \multicolumn{2}{|c|}{3207.997} & 4330.336 \\
\hline
\end{tabular}

\begin{tabular}{|c|c|c|c|c|c|c|c|c|}
\hline \multicolumn{4}{|c|}{ Atrribute } & \multicolumn{5}{|c|}{$\begin{array}{l}\text { Probability that at tribute is } \\
\text { tavorabie or present }\end{array}$} \\
\hline \multirow{5}{*}{$\begin{array}{l}\frac{d}{3} \\
\frac{2}{3} \\
\frac{\pi}{0} \\
\frac{\pi}{2} \\
\frac{\pi}{2}\end{array}$} & \multicolumn{3}{|l|}{ Hydrocarbon sources } & \multicolumn{5}{|c|}{$i$} \\
\hline & \multicolumn{3}{|l|}{ Timing } & \multicolumn{5}{|c|}{1} \\
\hline & \multicolumn{3}{|l|}{ Mienation } & \multicolumn{5}{|c|}{0.8} \\
\hline & \multicolumn{3}{|l|}{ Potential reservoir facies } & \multicolumn{5}{|c|}{0.5} \\
\hline & \multicolumn{3}{|l|}{ Marginal-play piotwisility } & \multicolumn{5}{|c|}{0.4} \\
\hline \multirow{4}{*}{ 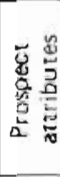 } & \multicolumn{3}{|l|}{ Trapping mechanism } & \multicolumn{5}{|c|}{0.3} \\
\hline & \multicolumn{3}{|l|}{ Effective porosity $1>3 \%$} & \multicolumn{5}{|c|}{0.1} \\
\hline & \multicolumn{3}{|c|}{ Hydropas bopn accumulation } & \multicolumn{5}{|c|}{0.4} \\
\hline & & \multicolumn{5}{|c|}{0.012} \\
\hline \multirow{6}{*}{ 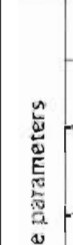 } & \multicolumn{3}{|c|}{ 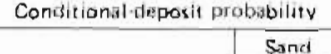 } & \multicolumn{5}{|c|}{ a } \\
\hline & Aesservoir Hithalogy & \multicolumn{2}{|c|}{ Carbonate } & \multicolumn{5}{|c|}{1} \\
\hline & \multirow{2}{*}{ Hydiocartbon inix } & \multirow{2}{*}{\multicolumn{2}{|c|}{ Gas }} & \multicolumn{5}{|c|}{0.4} \\
\hline & & & & \multicolumn{5}{|c|}{0.6} \\
\hline & \multirow{2}{*}{ Acuibute Figctilies } & \multicolumn{2}{|c|}{ Probubi } & inty of et & tqual to & o $0 \mathrm{gr}$ & ater 11 & \\
\hline & & 1.00 & 0.95 & 0.25 & 0,50 & 0.25 & 0.05 & 0 \\
\hline 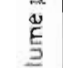 & $\begin{array}{c}\text { Area of clusure } \\
\left(\times 10^{y} \text { acies) }\right.\end{array}$ & 0.6 & 3 & 10 & 12 & 15 & 30 & 100 \\
\hline ? & $\begin{array}{l}\text { Reser voir thickness? } \\
\text { verticat closure fitl }\end{array}$ & .5 & 50 & 125 & 200 & 350 & 500 & 750 \\
\hline 要 & Eflective porosity $(\%)$ & 3 & 3 & 4 & 4 & 5 & 6 & 10 \\
\hline$\vec{I}$ & Trap fill $\{\%\}$ & 1 & 5 & 25 & 50 & 75 & 95 & 100 \\
\hline & $\begin{array}{l}\text { Reservoir dupth } \\
\left\{\times 10^{3}+t^{2}\right.\end{array}$ & 6 & 9 & 11 & 13 & 19 & 23 & 29 \\
\hline$\overline{\text { Numt }}$ & $\begin{array}{l}\text { of arillable prospects } \\
\text { play characteristic. }\end{array}$ & 2 & 4 & 4 & 5 & 8 & 10 & 20 \\
\hline
\end{tabular}

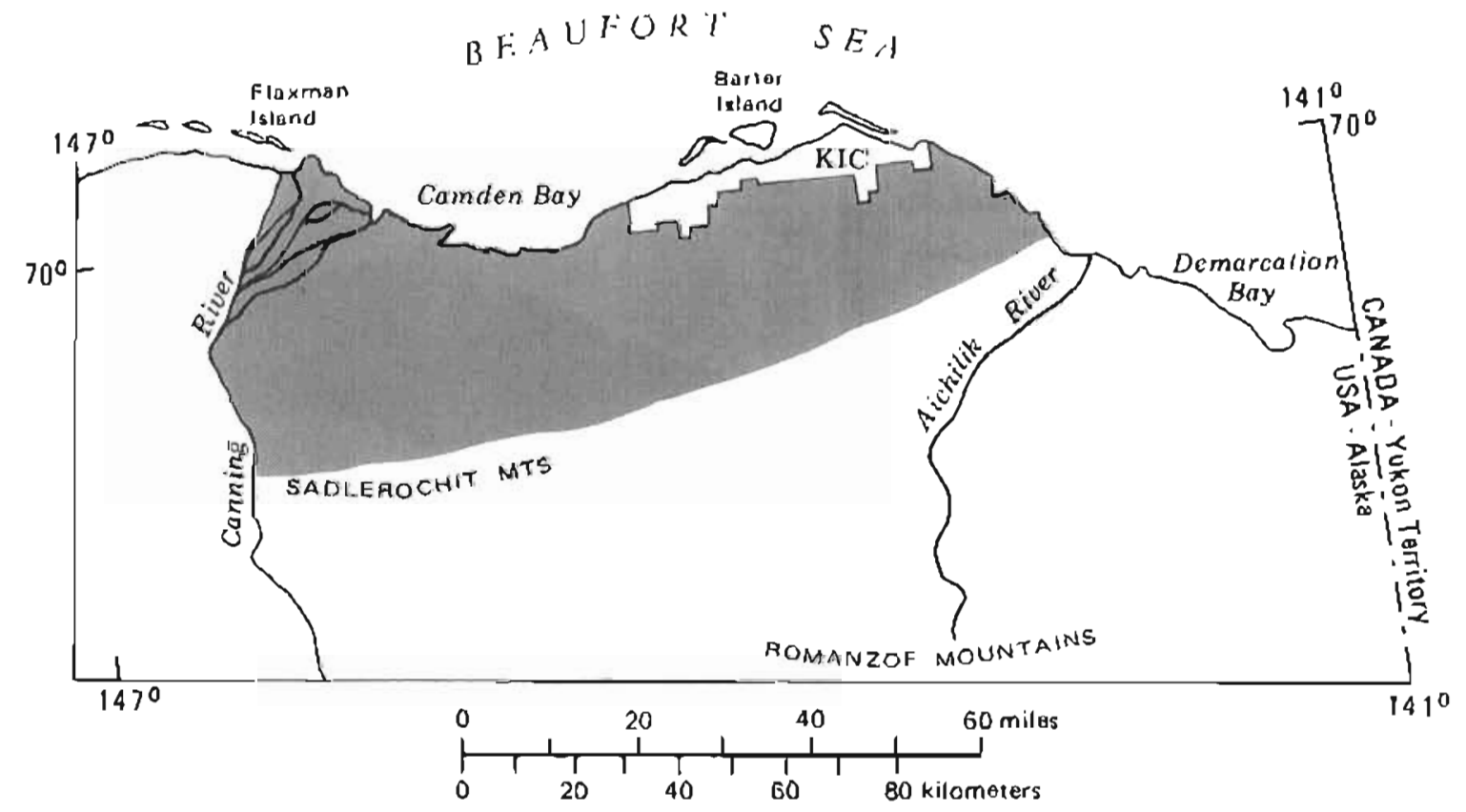

Figure 2. Areal distribution, inpul paramelers, and resources in place for the Lisburne Norlh Play, Arctic National Wildife Refuge, Alaska. 


\begin{tabular}{|c|c|c|c|}
\hline \multicolumn{4}{|c|}{$\begin{array}{l}\text { Gas fraction }=040 \\
\text { Conditional resources in place }\end{array}$} \\
\hline Fractile & $\begin{array}{c}\text { Oib } \\
\text { (million barrels) }\end{array}$ & Gias & $\begin{array}{l}\text { BOE. } \\
\text { (million) }\end{array}$ \\
\hline 0.95 & 0.00 & 0.00 & 000 \\
\hline 090 & 0.00 & 0.00 & 0.00 \\
\hline 0.75 & 0.00 & 0.00 & 000 \\
\hline 0.50 & 0.00 & 0.00 & 0.00 \\
\hline 0.25 & 0.00 & 0.00 & 0.00 \\
\hline 0,10 & 0.00 & 13.85 & 10.04 \\
\hline 0.05 & 64.03 & 170.30 & 129.34 \\
\hline 0.01 & 624.02 & 1021.80 & 777.91 \\
\hline Fractile & \multicolumn{2}{|c|}{$\begin{array}{l}\text { Deposir size } \\
\text { Coriditional. } \\
\text { loo\% asl } \\
\text { \{milion barrels\} }\end{array}$} & $\begin{array}{l}\text { Deposit sizz } \\
\text { Conditional, } \\
100 \% \text { gas } \\
\text { \{billion }\left\{1^{3}\right\}\end{array}$ \\
\hline 0.99 & \multicolumn{2}{|c|}{$3.81 \%$} & 2.779 \\
\hline 0.95 & \multicolumn{2}{|c|}{11.388} & 9.681 \\
\hline 0.90 & \multicolumn{2}{|c|}{19.488} & 17.355 \\
\hline 0.75 & \multicolumn{2}{|c|}{54.967} & 56.067 \\
\hline 0.50 & \multicolumn{2}{|c|}{163.679} & 172416 \\
\hline 0.25 & \multicolumn{2}{|c|}{406.565} & 454.902 \\
\hline 0.10 & \multicolumn{2}{|c|}{796.095} & 12.30 .341 \\
\hline 005 & \multicolumn{2}{|c|}{1536.064} & 2064430 \\
\hline 0.01 & \multicolumn{2}{|c|}{2277.339} & 5454.289 \\
\hline
\end{tabular}

\begin{tabular}{|c|c|c|c|c|c|c|c|c|}
\hline \multicolumn{4}{|c|}{ Altribule } & \multicolumn{5}{|c|}{$\begin{array}{c}\text { Probability that at tribute is } \\
\text { favorable or present }\end{array}$} \\
\hline \multirow{5}{*}{ 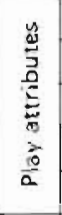 } & \multicolumn{3}{|l|}{ Hydrocarbon sources } & \multicolumn{5}{|c|}{1} \\
\hline & \multicolumn{3}{|l|}{ Timing } & \multicolumn{5}{|c|}{1} \\
\hline & \multicolumn{3}{|l|}{ Migestion } & \multicolumn{5}{|c|}{1} \\
\hline & \multicolumn{3}{|l|}{ Potential rezervair lacies } & \multicolumn{5}{|c|}{1} \\
\hline & \multicolumn{3}{|c|}{ Marginal-play prabability } & \multicolumn{5}{|c|}{1} \\
\hline \multirow{4}{*}{ 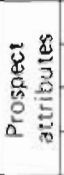 } & \multicolumn{3}{|l|}{ Trapping mechanism } & \multicolumn{5}{|c|}{0.25} \\
\hline & \multicolumn{3}{|l|}{ Effective porosity $(>3 \%)$} & \multicolumn{5}{|c|}{0.1} \\
\hline & \multicolumn{3}{|c|}{ Hiydrocarbon accumulation } & \multicolumn{5}{|c|}{0.4} \\
\hline & \multicolumn{3}{|c|}{ Conditional-deposit probability } & \multicolumn{5}{|c|}{0.01} \\
\hline \multirow{6}{*}{ 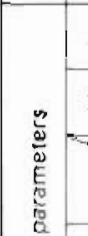 } & \multirow[b]{2}{*}{ Restrvair lithology } & \multicolumn{2}{|c|}{ Solnd } & \multicolumn{5}{|c|}{0} \\
\hline & & \multirow{2}{*}{\multicolumn{2}{|c|}{ Carbonate }} & \multicolumn{5}{|c|}{9} \\
\hline & \multirow{2}{*}{ Hydrocarbon mix } & & & \multicolumn{5}{|c|}{0.4} \\
\hline & & O: & & \multicolumn{5}{|c|}{$0 . \overline{6}$} \\
\hline & \multirow[b]{2}{*}{ Altribute } & \multicolumn{7}{|c|}{ Probability of equal to or greater than } \\
\hline & & 1.00 & 0.95 & 0.75 & 0.50 & 0.25 & 0.05 & 0 \\
\hline$\stackrel{\stackrel{\omega}{E}}{\underline{\underline{E}}}$ & $\begin{array}{l}\text { Area of ciosure } \\
\left\{x: 0^{3} \text { acres } \mid\right.\end{array}$ & 0.6 & 1 & 3 & 5 & 10 & 30 & 100 \\
\hline $\begin{array}{l}9 \\
3 \\
\vdots \\
0\end{array}$ & $\begin{array}{l}\text { Reservall thickness/ } \\
\text { mertical closure (ft) }\end{array}$ & 5 & 100 & 225 & 350 & 425 & 600 & 1200 \\
\hline 8 & EHective porosity $(\%)$ & 3 & 3 & 4 & 4 & 5 & 6 & 10 \\
\hline$\frac{\check{z}}{1}$ & Trap $\left.|\| l|{ }^{\prime}\right)$ & 1 & 5 & 25 & 50 & 76 & 95 & 100 \\
\hline & $\begin{array}{l}\text { Aeservoit depth } \\
\left\{\times 10^{3} \mid \mathrm{t}\right\}\end{array}$ & 2 & 5 & 7 & 9 & 12 & 14 & 20 \\
\hline Numb & $\begin{array}{l}\text { et al drillaule prospects } \\
\text { play characteristic) }\end{array}$ & 1 & 6 & 8 & 10 & 15 & 25 & 100 \\
\hline
\end{tabular}

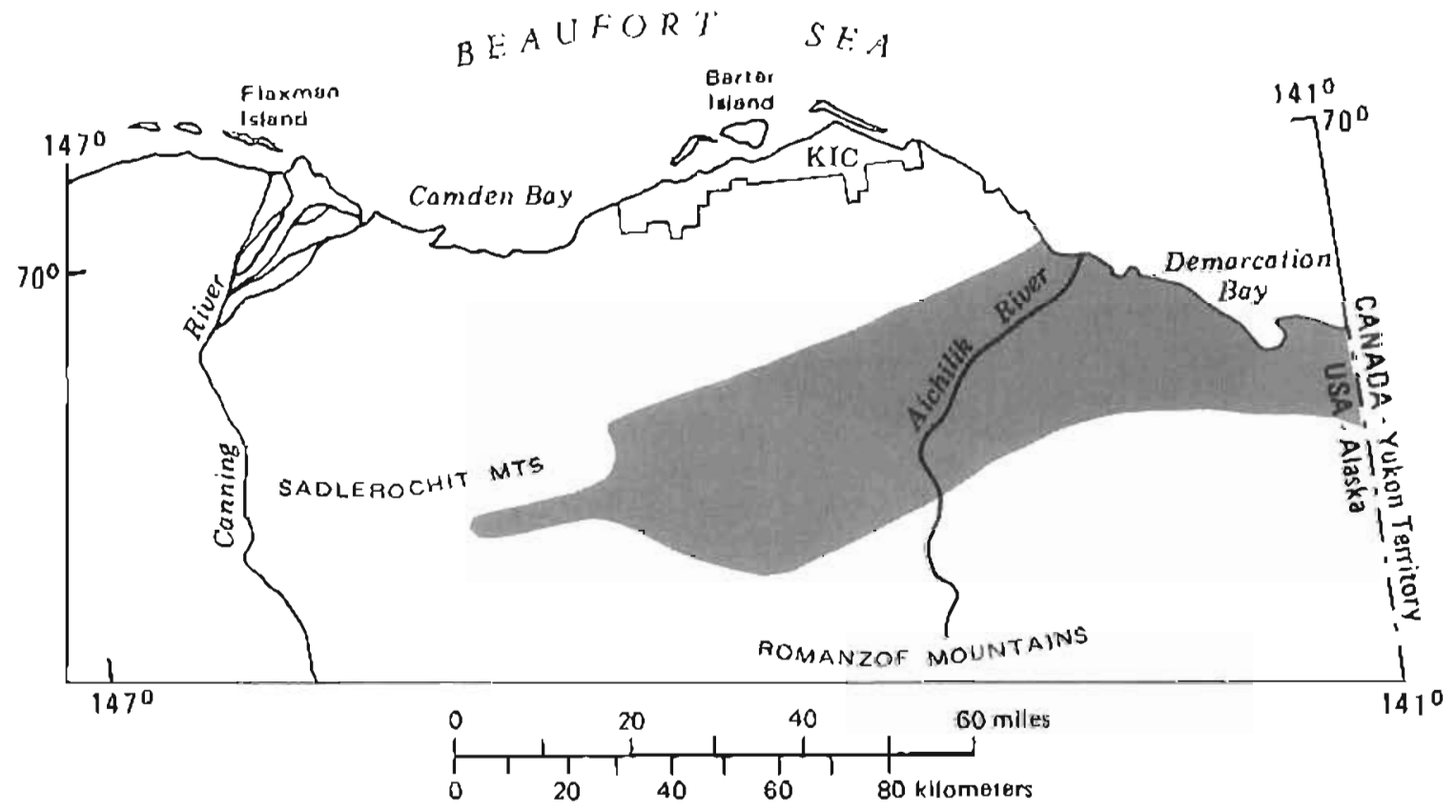

Figure 3. Areal distribution, inpul paramelers, and resources in place for the Lisburne South Play. Arclic National Wildlife Refuge, Alaska. 


\begin{tabular}{|c|c|c|c|}
\hline \multicolumn{4}{|c|}{$\begin{array}{l}\text { Gas Praction }=0.40 \\
\text { Conditional resources in place }\end{array}$} \\
\hline Fractile & $\begin{array}{l}\text { Ond } \\
\text { (millian barrels) }\end{array}$ & $\begin{array}{l}\text { Gas } \\
\text { (billion }\left(?^{3}\right)\end{array}$ & $\begin{array}{c}\text { BOE } \\
\text { (miltion) }\end{array}$ \\
\hline 099 & 0.00 & 0.00 & 0.00 \\
\hline 0.95 & 0.00 & 0.00 & 0.00 \\
\hline 0.90 & 0.00 & 0.00 & 0.00 \\
\hline 0.75 & 000 & 0.00 & 0.00 \\
\hline 0.50 & 0.00 & 0.00 & 0.00 \\
\hline 0.25 & 0.00 & 689.02 & 292.14 \\
\hline 0.10 & 948.85 & 2927.37 & 1339.20 \\
\hline 0.05 & 1927.34 & 5123.80 & 2619.52 \\
\hline 001 & 5981.70 & 11366.90 & 7005.12 \\
\hline Fractile & \multicolumn{2}{|c|}{$\begin{array}{l}\text { Deposit sizo } \\
\text { Conditionsi. } \\
100 \% \text { oll } \\
\text { (million barrels) }\end{array}$} & $\begin{array}{c}\text { Deposit size } \\
\text { Conditional. } \\
100 \% \text { gas } \\
\left(\text { bullian } \mathrm{ft}^{3} \text { ) }\right.\end{array}$ \\
\hline 0.99 & 11.11 & & 15.476 \\
\hline 0.95 & 11.46 & & 53.727 \\
\hline 0.90 & 70.17 & & $148 \cup 26$ \\
\hline 0.75 & 174.01 & & 417946 \\
\hline 0.50 & 538.91 & & 1163.055 \\
\hline 0.25 & 1323.92 & & 2905.923 \\
\hline 0.10 & 2925.32 & & 5803.098 \\
\hline 0.05 & 4333.50 & & 7478.438 \\
\hline 0.01 & 9932.54 & & 14709.691 \\
\hline
\end{tabular}

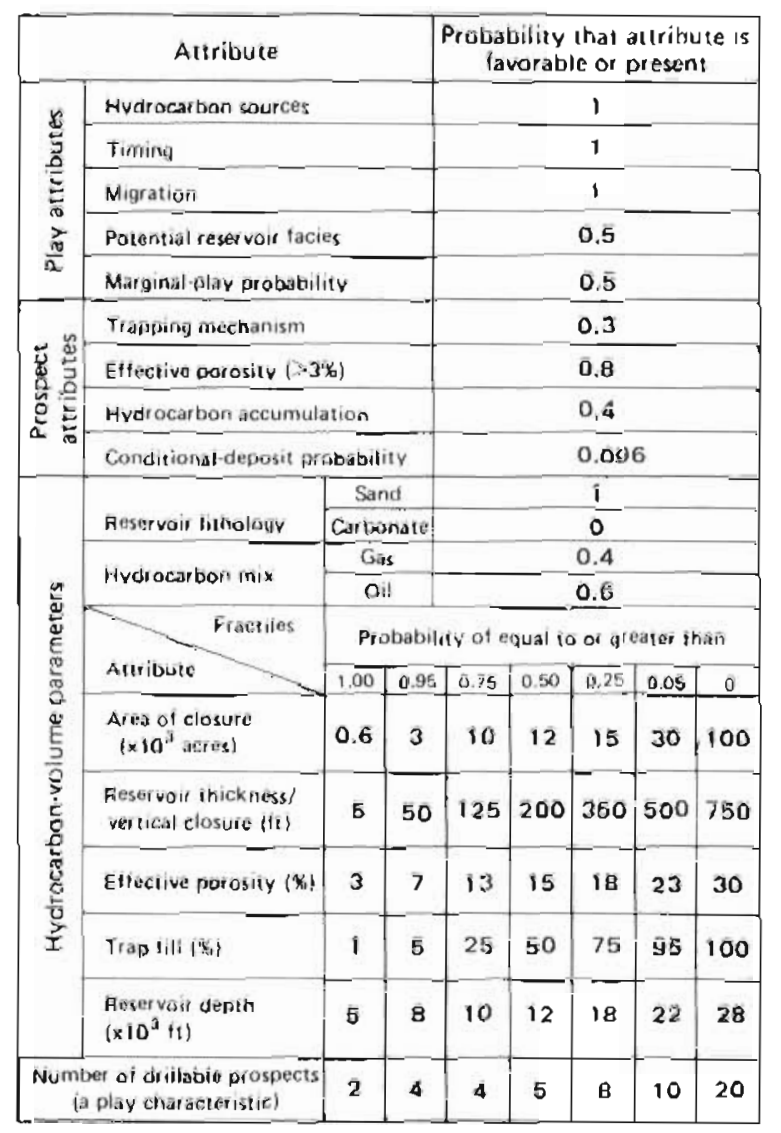

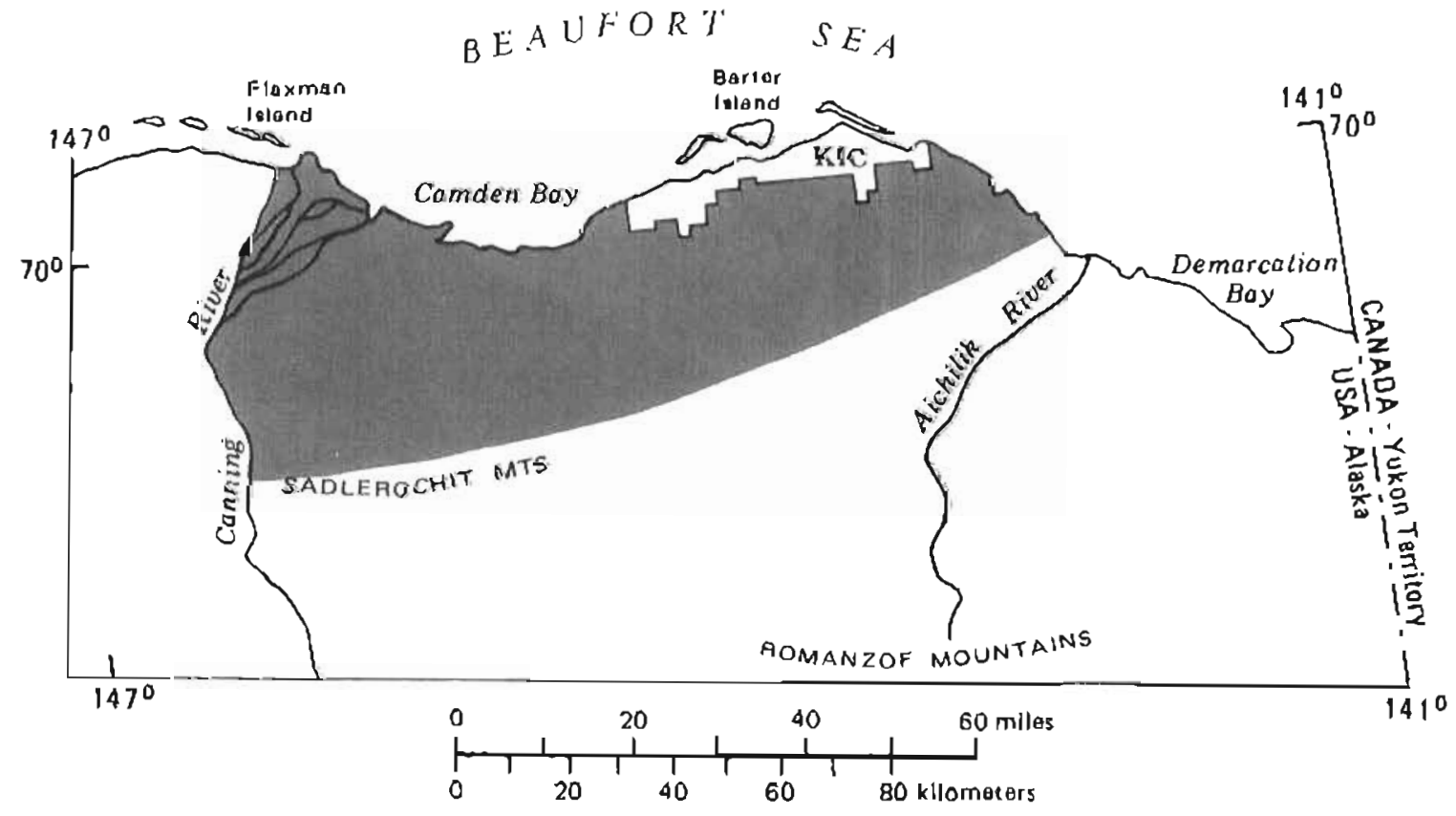

Figure 4. Areal distribution, inpul parameters, and resources in place for the Permian-Triassic Clastics Norlh Play, Arclic National Wildife Refuge, Alaska. 


\begin{tabular}{|c|c|c|c|}
\hline \multirow[b]{2}{*}{ Fractile } & \multicolumn{2}{|c|}{$\begin{array}{l}\text { Gas fraction }=040 \\
\text { Conditional resources in place }\end{array}$} & \multirow[b]{2}{*}{$\begin{array}{c}\text { BOE } \\
\text { (million) }\end{array}$} \\
\hline & $\begin{array}{c}\text { Oll } \\
\text { (million barrels) }\end{array}$ & $\begin{array}{l}\text { Gas } \\
\left.\text { (billion } t^{3}\right)^{3}\end{array}$ & \\
\hline 0.99 & 0.00 & 0.00 & 0.00 \\
\hline 035 & 000 & 0.00 & 0.00 \\
\hline 0.90 & 000 & 0.00 & 0.00 \\
\hline 0,75 & 0.00 & 0.00 & 0.00 \\
\hline 0.50 & 000 & $7 ! .45$ & 50104 \\
\hline 0.25 & 420.35 & 847.34 & 704.19 \\
\hline 0.10 & 1923.32 & 2875.17 & 2514.74 \\
\hline 0.05 & 3892.57 & 5362.30 & 4698.88 \\
\hline 0.01 & 9535.30 & 13478.01 & 11477.75 \\
\hline Fractile & $\begin{array}{r}\text { Depos } \\
\text { Condi } \\
100 \% \\
\text { Imillion }\end{array}$ & & $\begin{array}{c}\text { Deposit size } \\
\text { Conditional. } \\
100 \% \text { gas } \\
\text { (billion } \mathrm{it}^{3} \text { ) }\end{array}$ \\
\hline 099 & & & 6.613 \\
\hline 0.95 & 19. & & 23.007 \\
\hline 1) 30 & 41. & & 53.101 \\
\hline $0.1 !$ & 141. & & 156.387 \\
\hline 0.40 & 424. & & 545.440 \\
\hline 0.25 & 1127. & & 1495.480 \\
\hline 0.10 & 2926. & & 3769.860 \\
\hline 0.05 & 4662 & & 6053.766 \\
\hline 0.01 & 9940. & & 19075.750 \\
\hline
\end{tabular}

\begin{tabular}{|c|c|c|c|c|c|c|c|c|}
\hline \multicolumn{4}{|c|}{ Altribule } & \multicolumn{5}{|c|}{$\begin{array}{c}\text { Probability that attribute is } \\
\text { Iavorable or present }\end{array}$} \\
\hline \multirow{5}{*}{ 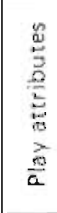 } & \multicolumn{3}{|l|}{ Hydrocarlyon saurces } & \multicolumn{5}{|c|}{1} \\
\hline & \multicolumn{3}{|l|}{ Timing } & \multicolumn{5}{|c|}{1} \\
\hline & \multicolumn{3}{|l|}{ Migrątion } & \multicolumn{5}{|c|}{$\uparrow$} \\
\hline & \multicolumn{3}{|l|}{ Potent ial seser vair lacies } & \multicolumn{5}{|c|}{1} \\
\hline & \multicolumn{3}{|l|}{ Murgnal-play probabishy } & \multicolumn{5}{|c|}{1} \\
\hline \multirow{4}{*}{ 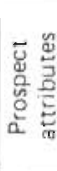 } & \multicolumn{3}{|l|}{ Trapping mechanism } & \multicolumn{5}{|c|}{0.25} \\
\hline & \multicolumn{3}{|l|}{ Effecilive porosity $>3 \%$} & \multicolumn{5}{|c|}{0.8} \\
\hline & \multicolumn{3}{|c|}{ Hyitrocarban accurnulation } & \multicolumn{5}{|c|}{0.4} \\
\hline & \multicolumn{3}{|c|}{ Conditional-deposit probabitity } & \multicolumn{5}{|c|}{0.08} \\
\hline \multirow{6}{*}{ 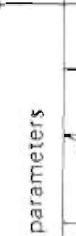 } & \multirow[b]{2}{*}{ Reservoir lithalogy } & \multicolumn{2}{|c|}{ Sand } & \multicolumn{5}{|c|}{1} \\
\hline & & \multicolumn{2}{|c|}{ Carbonate } & \multicolumn{5}{|c|}{0} \\
\hline & \multirow{2}{*}{ Hydrocar ban mix } & $\mathrm{Ga}$ & & \multicolumn{5}{|c|}{0.4} \\
\hline & & \multicolumn{2}{|c|}{ Oii } & \multicolumn{5}{|c|}{0.6} \\
\hline & \multirow{2}{*}{ Altritute } & \multicolumn{7}{|c|}{ Probstility of equal to or greater than } \\
\hline & & 1.00 & 0.95 & 0.75 & 0.50 & 0.25 & 0.05 & $a$ \\
\hline है & $\begin{array}{l}\text { Area of closure } \\
\left\{\times 10^{3} \text { acres }\right\}\end{array}$ & 0.6 & 1 & 3 & 5 & 10 & 30 & 100 \\
\hline ? & $\begin{array}{l}\text { Reser yoir thickness/ } \\
\text { vesticat closure if!? }\end{array}$ & 5 & 100 & 225 & 350 & 425 & 600 & 1000 \\
\hline 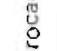 & Etteclive parosity $\{$ wh & 3 & 7 & 13 & 15 & 18 & 23 & 30 \\
\hline I & Trap till $\langle \%\rangle$ & 1 & 5 & 25 & 50 & 75 & 95 & 100 \\
\hline & $\begin{array}{l}\text { Reser woll tepth } \\
\left(\times 10^{3} \mathrm{fr}\right)\end{array}$ & 2 & 4 & 6 & 8 & 11 & 13 & 20 \\
\hline Num & $\begin{array}{l}\text { ef of chrilable prospects } \\
\text { play characteristic) }\end{array}$ & 1 & 5 & 8 & 10 & 15 & 25 & 100 \\
\hline
\end{tabular}

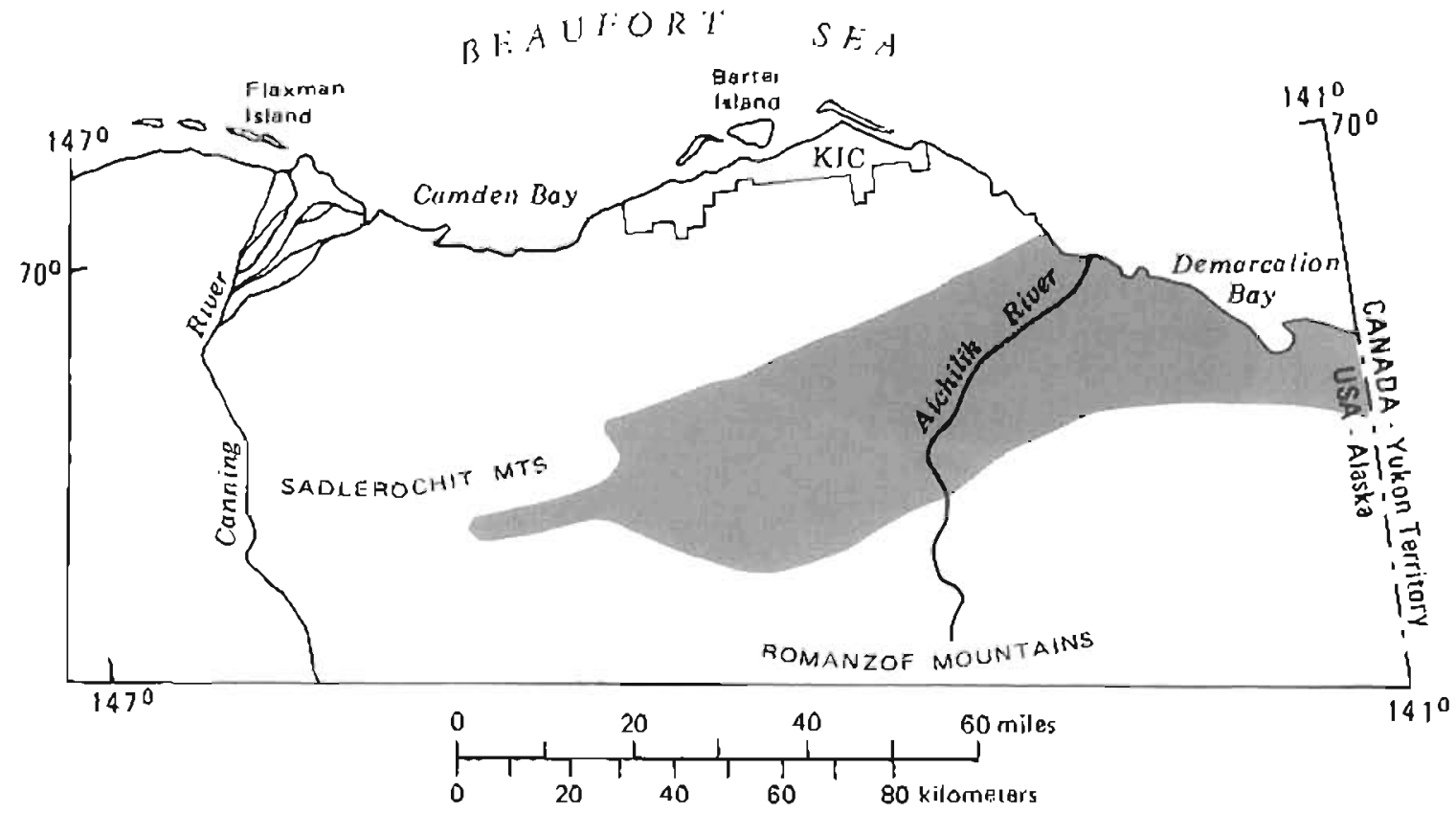

Figure 5 Areal distribution, inpul parameters, and resources in place for the Permian-Triassic Clastics Souch Play. Arctic National Wilkllife Refuge, Alaska. 


\begin{tabular}{|c|c|c|c|}
\hline \multicolumn{4}{|c|}{$\begin{array}{c}\text { Gas traction }=0.40 \\
\text { Conditional resources in place }\end{array}$} \\
\hline Fraciile & 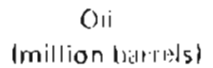 & $\begin{array}{l}\text { Gas } \\
\left.\text { (billion } t^{3}{ }^{3}\right)\end{array}$ & $\begin{array}{l}\text { BOE } \\
\text { (million) }\end{array}$ \\
\hline 0.99 & 000 & 0.00 & 0.00 \\
\hline 0.95 & 0.00 & 000 & 0.00 \\
\hline 090 & 0.00 & 0.00 & 000 \\
\hline 0.75 & 0.00 & 0.00 & 0.00 \\
\hline $0.5(3)$ & 0.00 & 124.91 & 77.60 \\
\hline 0.210 & 3277 & 1075.43 & 654.49 \\
\hline 0.10 & 1607.76 & 3468.63 & 2248.06 \\
\hline 0.05 & 3122.80 & 592973 & 4097.80 \\
\hline 0.01 & 7838.41 & 15008.58 & 9200.97 \\
\hline Fraculle & $\begin{array}{l}\text { Depos } \\
\text { Candi } \\
100 \% \\
\text { (million }\end{array}$ & & $\begin{array}{c}\text { Deposul size } \\
\text { Condinional, } \\
100 \% \text { das } \\
\text { \{billion }\left\{1^{3}\right\}\end{array}$ \\
\hline 0.99 & \multicolumn{2}{|c|}{1.902} & 3.359 \\
\hline 0.95 & \multicolumn{2}{|c|}{7.342} & 14.279 \\
\hline 090 & \multicolumn{2}{|c|}{14.607} & 28.752 \\
\hline 0.75 & \multicolumn{2}{|c|}{47.014} & 88.333 \\
\hline 0.50 & \multicolumn{2}{|c|}{163.259} & 283.541 \\
\hline 0.25 & \multicolumn{2}{|c|}{523.658} & 891.588 \\
\hline 0.10 & \multicolumn{2}{|c|}{1602893} & $266\{3.084$ \\
\hline 0.05 & \multicolumn{2}{|c|}{2813698} & 4705.582 \\
\hline 0.01 & \multicolumn{2}{|c|}{7445.875} & 14078.285 \\
\hline
\end{tabular}

\begin{tabular}{|c|c|c|c|c|c|c|c|c|}
\hline \multicolumn{4}{|c|}{ Altribute } & \multicolumn{5}{|c|}{$\begin{array}{c}\text { Probahility that attribute is } \\
\text { favarable or present }\end{array}$} \\
\hline \multirow{5}{*}{ 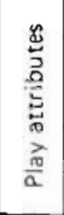 } & \multicolumn{3}{|l|}{ Hydrocarbun sources } & \multicolumn{5}{|c|}{1} \\
\hline & \multicolumn{3}{|l|}{ Timing } & \multicolumn{5}{|c|}{1} \\
\hline & \multicolumn{3}{|l|}{ Migration } & \multicolumn{5}{|c|}{1} \\
\hline & \multicolumn{3}{|l|}{ Potential reservor tacies } & \multicolumn{5}{|c|}{1} \\
\hline & \multicolumn{3}{|l|}{ Maruinal-olay probability } & \multicolumn{5}{|c|}{1} \\
\hline \multirow{4}{*}{ 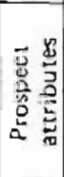 } & \multicolumn{3}{|l|}{ Trapping mechanism } & \multicolumn{5}{|c|}{$\overline{0.25}$} \\
\hline & \multicolumn{3}{|l|}{ Effective porosity $>3 \%$ ) } & \multicolumn{5}{|c|}{0.9} \\
\hline & \multicolumn{3}{|c|}{ Hydracarbon acceumulation } & \multicolumn{5}{|c|}{0.4} \\
\hline & \multicolumn{3}{|c|}{ Conditianit depasit prabability } & \multicolumn{5}{|c|}{0.09} \\
\hline \multirow{6}{*}{ 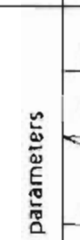 } & \multirow[b]{2}{*}{ Aeservair lithology } & \multicolumn{2}{|c|}{ Sanci } & \multicolumn{5}{|c|}{1} \\
\hline & & \multicolumn{2}{|c|}{ Carbonate } & \multicolumn{5}{|c|}{0} \\
\hline & \multirow{2}{*}{ Hydrocarbon mix } & \multicolumn{2}{|c|}{ Gas } & \multicolumn{5}{|c|}{0.4} \\
\hline & & $\mathrm{Oi}$ & & \multicolumn{5}{|c|}{$\overline{0.6}$} \\
\hline & \multirow[b]{2}{*}{ Altribute } & \multicolumn{7}{|c|}{ Probability of equal to as greater than } \\
\hline & & 1.00 & 0.95 & 0.75 & 0.50 & 0.25 & 0.05 & 0 \\
\hline$\frac{2}{5}$ & $\begin{array}{l}\text { Area of closure } \\
\left\{\times 10^{3} \text { acces }\right]\end{array}$ & 0.6 & 2 & 3 & 5 & 15 & 40 & 100 \\
\hline $\begin{array}{l}0 \\
3 \\
2 \\
0 \\
0 \\
0\end{array}$ & $\begin{array}{l}\text { Reservoir (hickniss) } \\
\text { vertical closura (hit) }\end{array}$ & 5 & 25 & 50 & 100 & 200 & 350 & 600 \\
\hline 苋 & Elfective norosity $(\%)$ & 3 & 5 & 10 & 15 & 20 & 25 & 30 \\
\hline$\frac{1}{I}$ & Yrap lill (*) & 1 & 6 & 30 & 60 & 80 & 96 & 100 \\
\hline & $\begin{array}{l}\text { Reservain depth } \\
\left(\times 10^{x}(1)\right.\end{array}$ & 2 & 5 & 8 & 10 & 15 & 20 & 26 \\
\hline Num! & $\begin{array}{l}\text { er ol arillabte prospects } \\
\text { piay t:firacteristici }\end{array}$ & 2 & 3 & $G$ & 12 & 25 & 60 & 100 \\
\hline
\end{tabular}

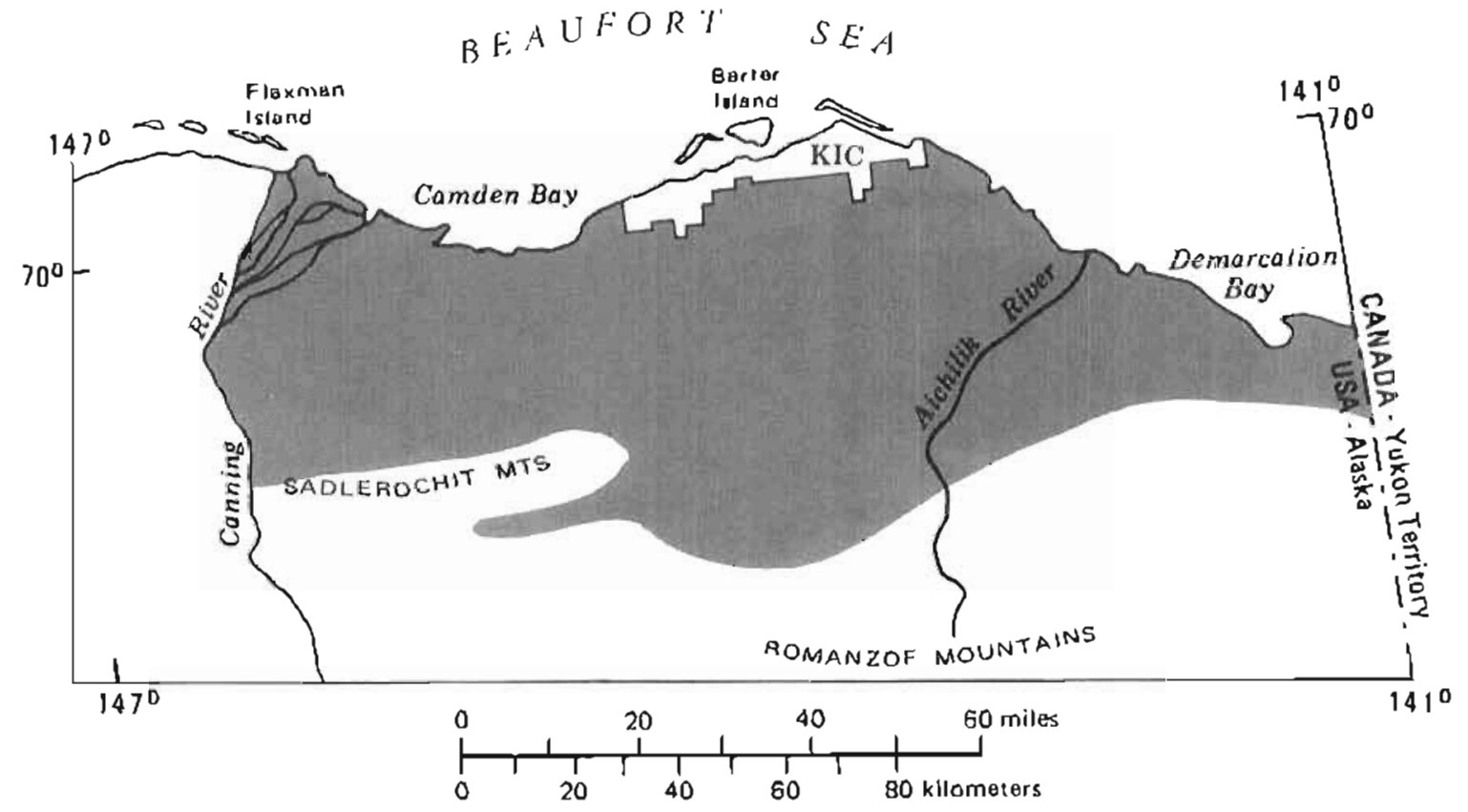

Figure 6. Areal distrilsution, inpul parameters, and resources in place for the Kemik-Thomson Play, Arctic National Wildlife Refuge, Alaska 


\begin{tabular}{|c|c|c|c|}
\hline \multirow[b]{2}{*}{ Frascilra } & \multicolumn{2}{|c|}{$\begin{array}{l}\text { Gas fraction }=0.50 \\
\text { Conditional resources in place }\end{array}$} & \multirow[b]{2}{*}{$\begin{array}{c}\text { BOE } \\
\text { (mition) }\end{array}$} \\
\hline & $\begin{array}{l}\text { Oil } \\
\text { (million barrels) }\end{array}$ & Gas & \\
\hline 0.99 & 0.00 & 0.00 & 0.00 \\
\hline 0.95 & 0.00 & 12.35 & 9.06 \\
\hline 0.90 & 0.00 & 224.04 & 146.23 \\
\hline 0.75 & 326.40 & 1498.50 & 1044.79 \\
\hline 0.50 & 209778 & 554416 & 3785.89 \\
\hline 0.25 & 6972.20 & 13623.56 & 9514.61 \\
\hline 0.10 & 15625.20 & 28032.78 & 19546.79 \\
\hline 0.05 & 2423045 & 38904.07 & 29454.32 \\
\hline 0.01 & 43382.48 & 24349.25 & 48926.22 \\
\hline Fracule & $\begin{array}{l}\text { Depo: } \\
\text { Condi } \\
100 \% \\
\text { (million }\end{array}$ & & $\begin{array}{l}\text { Deposit size } \\
\text { Conditional, } \\
100 \% \text { gas } \\
\text { (biltion } \mathrm{t}^{3} \text { ) }\end{array}$ \\
\hline 0.99 & & & 7.255 \\
\hline 0.95 & 27 & & $2 i 1.025$ \\
\hline 0.90 & 44 & & 54.634 \\
\hline 0.75 & 137 & & 171.947 \\
\hline 0.50 & 462 & & 603.463 \\
\hline 0.25 & 1542 & & 2044.293 \\
\hline 0.10 & 4489 & & 5808.051 \\
\hline 0.05 & 7927 & & 10985.301 \\
\hline 0.01 & 24037 & & 32045.930 \\
\hline
\end{tabular}

\begin{tabular}{|c|c|c|c|c|c|c|c|c|}
\hline \multicolumn{4}{|c|}{ Altribute } & \multicolumn{5}{|c|}{$\begin{array}{l}\text { Probabilizy that altribute is } \\
\text { favorable or prosent }\end{array}$} \\
\hline \multirow{5}{*}{ 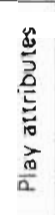 } & \multicolumn{3}{|l|}{ Hyurocartion sources } & \multicolumn{5}{|c|}{1} \\
\hline & \multicolumn{3}{|l|}{ Timing } & \multicolumn{5}{|c|}{1} \\
\hline & \multicolumn{3}{|l|}{ Migration } & \multicolumn{5}{|c|}{1} \\
\hline & \multicolumn{3}{|l|}{ Potential reservoir facies; } & \multicolumn{5}{|c|}{1} \\
\hline & \multicolumn{3}{|l|}{ Marginal-plav probability } & \multicolumn{5}{|c|}{$\overline{1}$} \\
\hline \multirow{4}{*}{ 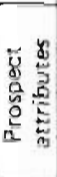 } & \multicolumn{3}{|l|}{ Trapping mechnnism } & \multicolumn{5}{|c|}{$\overline{0.25}$} \\
\hline & \multicolumn{3}{|l|}{ Elfective porosity $\left(=3 x_{1}\right)$} & \multicolumn{5}{|c|}{1} \\
\hline & \multicolumn{3}{|c|}{ Hydrocarbon accumulation } & \multicolumn{5}{|c|}{0.5} \\
\hline & \multicolumn{3}{|c|}{ Conditionaleteposit probability } & \multicolumn{5}{|c|}{0.125} \\
\hline \multirow{6}{*}{ 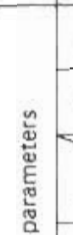 } & \multirow[b]{2}{*}{ Fieservoir lithology } & \multicolumn{2}{|c|}{ Sund } & \multicolumn{5}{|c|}{1} \\
\hline & & \multicolumn{2}{|c|}{ Carbonate } & \multicolumn{5}{|c|}{0} \\
\hline & \multirow{2}{*}{ Hydrocarbon mix } & \multicolumn{2}{|c|}{ Gas } & \multicolumn{5}{|c|}{0.5} \\
\hline & & \multicolumn{2}{|c|}{ Qil } & \multicolumn{5}{|c|}{0.5} \\
\hline & Fractiles & \multicolumn{7}{|c|}{ Probability of equal to or greater than } \\
\hline & Attribute & 1,00 & 0.95 & 0.35 & 0.50 & 0.25 & 0.05 & 0 \\
\hline$\frac{\Phi}{E}$ & $\begin{array}{l}\text { Aved at closure } \\
\left(\times 10^{3} \text { acres }\right)\end{array}$ & 0.6 & 1 & 2 & 4 & 12 & 30 & 75 \\
\hline $\begin{array}{l}9 \\
\stackrel{3}{c} \\
0 \\
0\end{array}$ & $\begin{array}{l}\text { Reser woir thick ness) } \\
\text { vertical closure (fit) }\end{array}$ & 50 & 100 & 200 & 300 & 800 & 1200 & 2000 \\
\hline gู & Effeclive porosity $\left\{x_{1}\right\}$ & 3 & 5 & 10 & 15 & 39 & 23 & 30 \\
\hline i & Trage till $\left|x^{\prime}\right\rangle$ & 1 & 6 & 30 & 60 & 80 & 96 & 100 \\
\hline & $\begin{array}{l}\text { Resenvolt dupth } \\
\left(\times 10^{3} \mathrm{ill}\right.\end{array}$ & 2 & 3 & 4 & 6 & 9 & 12 & 20 \\
\hline Numb & $\begin{array}{l}\text { er of ofillable prospects } \\
\text { plây characteristic) }\end{array}$ & Б & 10 & 26 & 40 & 70 & 100 & 200 \\
\hline
\end{tabular}

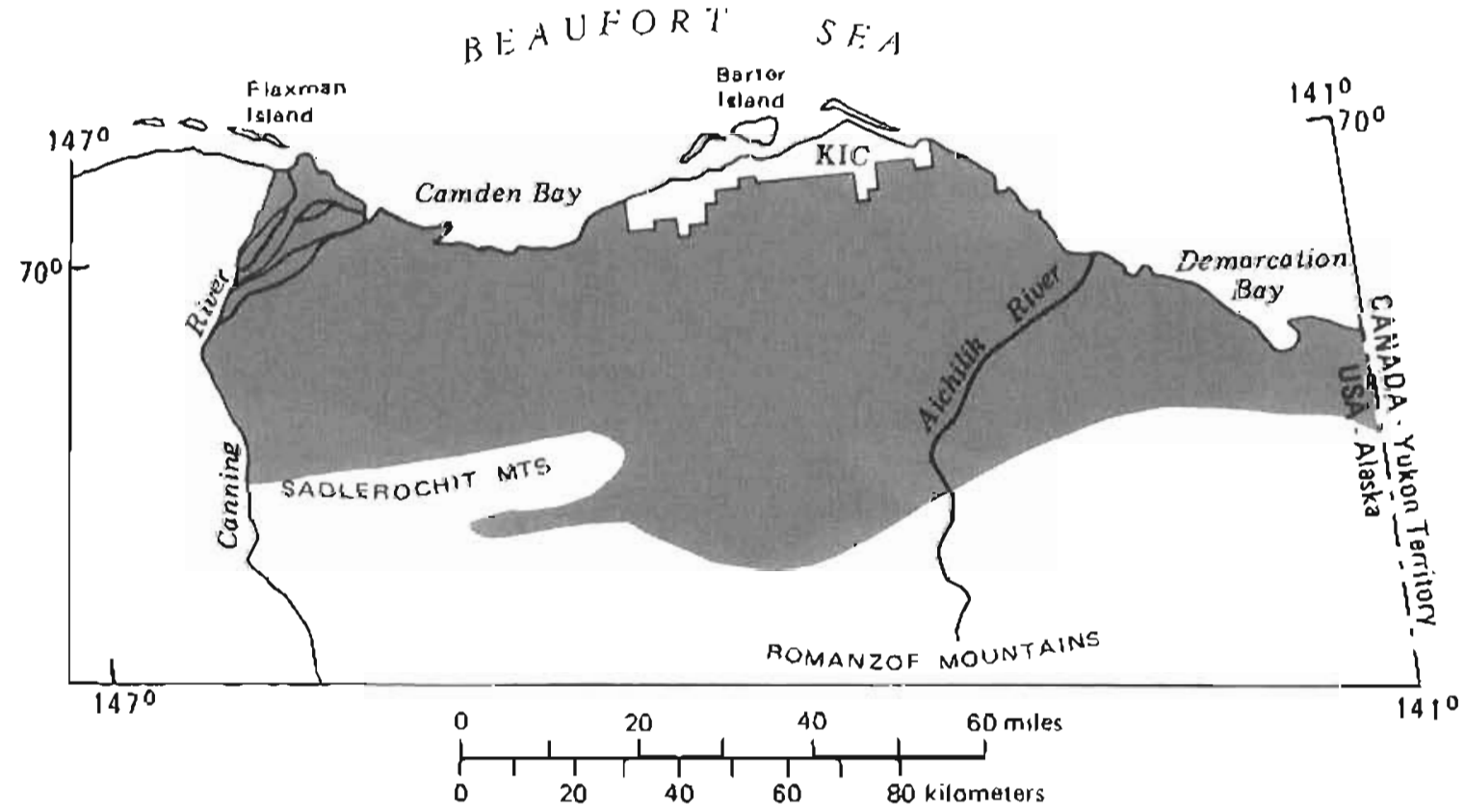

Figure 7. Areal distribution, inpul paramelers, and resources in place for the Post-Albian Clastics Play, Arctic National Wildilife Refuge, Alaska. 


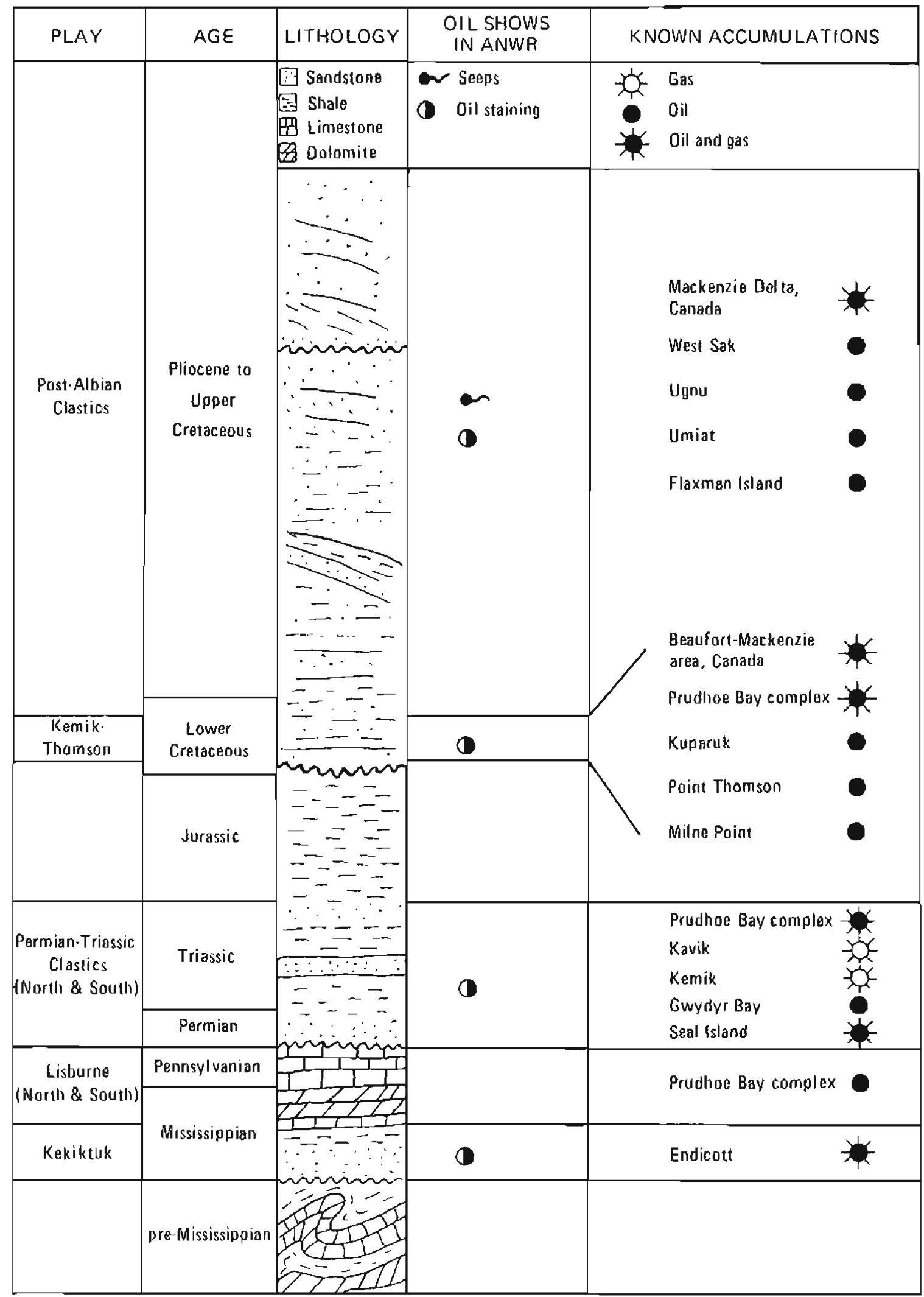

Figure 8. Stratigraphic column and oil-and-gas summary for plays in the Arctic National Wildlife Refuge, Alaska. 